\title{
Фізична терапія осіб зрілого віку з дискогенною патологією поперекового відділу хребта з використанням технічних засобів
}

\author{
УДК: 617.559-053.88:615.825+616-085
}

\section{I. О. Жарова, Н. В. Чечер}

Національний університет фізичного виховання і спорту України, Київ, Україна

\begin{abstract}
Резюме. Фізична терапія посідає одне з найважливіших місць у відновному лікуванні осіб з дискогенною патологією хребта, оскільки використання засобів фізичної терапії дає можливість патогенетичного впливу на проблему, усуваючи не лише наслідок, але і її причину. Мета. Проаналізувати досвід зарубіжних та вітчизняних авторів щодо використання механотерапії для осіб з дискогенною патологією поперекового відділу хребта. Методи. Аналіз та узагальнення науково-методичної літератури. Результати. У роботі узагальнено досвід використання технічних засобів з дискогенною патологією поперекового відділу хребта. Охарактеризовано основні стратегії використання механотерапії. Висновки. Механотерапію у системі фізичної терапії застосовують як самостійний засіб, так і включають у комплекси лікувальної гімнастики та апаратного масажу в основну її частину. У перспективі планується розробка програми фізичної терапії осіб з дискогенною патологією поперекового відділу хребта з використанням технічних засобів.

Ключові слова: фізична терапія, опорно-руховий апарат, дискогенна патологія, технічні засоби.
\end{abstract}

Physical therapy of adults with a diskogenic pathology of the lumbar spine using technological means

\section{O. Zharova, N. V. Checher}

National University of Physical Education and Sport of Ukraine, Kyiv, Ukraine

\begin{abstract}
Physical therapy occupies one of the most important places in the rehabilitation of persons with discogenic spinal pathology, since the use of physical therapy provides a pathogenetic influence on the problem, eliminating not only the consequence but also its cause. Objective. To analyze the experience of foreign and domestic authors on the use of mechanotherapy for persons with discogenic pathology of the lumbar spine. Methods. Analysis and generalization of scientific and methodological literature. Results. The paper summarizes the use of equipment with discogenic pathology of the lumbar spine. The main strategies for the use of mechanotherapy are described. Conclusions. Mechanotherapy in the system of physical therapy is used as an independent tool, and included in the complexes of therapeutic gymnastics and instrumental massage in its main part. In the future it is planned to develop a program of physical therapy for persons with discogenic pathology of the lumbar spine using technical means.

Keywords: physical therapy, musculoskeletal system, discogenic pathology, technical means.
\end{abstract}

Постановка проблеми. Аналіз останніх досліджень та публікацій. За даними авторів, від 50 до 80 \% населення соціально активного віку (30-60 років) періодично лікуються від больових відчуттів, що пов'язані із грижами різних відділів хребта. У структурі неврологічної захворюваності поперекові больові синдроми міцно утримують перше місце за поширеністю, за кількістю днів і випадків непрацездатності. Із усіх захворювань нервової системи на неї припадає близько 80 \% випадків тимчасової втрати працездатності. 
Огляд літератури показав, що вивчення проблеми терапії цієї групи хворих належить до важливих напрямів наукових досліджень. У зв'язку 3 цим актуальним $€$ питання розробки та впровадження терапевтичних заходів для осіб з дискогенною патологією у поперековому відділі хребта. У сучасній фрізичній терапії широко використовують технічні засоби відновлення різних типів i конструкцій. Серед них для відновлення функціонального стану опорно-рухового апарату людини, особливо при дискогенній патології поперекового відділу хребта, значне місце посідають спеціалізовані технічні засоби для забезпечення тракційної терапії. Для підвищення ефрективності відновлення людини після дискогенної патології у поперековому відділі хребта застосовують і достатньо прості механічні тракційні засоби, які забезпечують проведення активної фрізичної терапії, процедур відновлення стану організму після фрізичних навантажень не тільки в клінічних умовах а й в умовах фрітнес-центрів, клубів і домашніх умовах. Незважаючи на існування різноманітних тракційних систем для фрізичної терапії та профрілактики захворювань і пошкоджень хребта, ще мало задіяні новітні сучасні технічні засоби з використанням зворотного зв'язку, що ефективно забезпечують фрункції витягнення хребтового стовпа у всіх його відділах $[3,6,10,11]$.

Мета дослідження - проаналізувати досвід зарубіжних та вітчизняних авторів щодо використання механотерапевтичних апаратів для осіб з дискогенною патологією поперекового відділу хребта.

Методи дослідження - узагальнення й аналіз науково-методичної літератури.

Зв'язок роботи 3 науковими програмами, планами, темами. Робота виконана відповідно до «Плану НДР НУФВСУ на 2016-2020 рр.» за темою 4.2 «Організаційні та теоретико-методичні основи фрізичної реабілітації осіб різних нозологічних, професійних та вікових груп» (номер держреєстрації 0116U001609).

Результати дослідження та їх обговорення. Аналіз вітчизняної і зарубіжної літератури показує, що особливості застосування механотерапії і її ефрективність при травмах і захворюваннях опорно-рухового апарату вивчені недостатньо. Основним критерієм під час оцінки ефективності механотерапії в комплексному відновному лікуванні на сьогодні $€$ її кількісна характеристика. Цей показник, безсумнівно, важливий, але він не завжди може служити абсолютним орієнтиром для об'єктивних висновків щодо реактивності цілісного організму, його адаптаційних і потенційних можливостей.
Останнім часом використовують багато видів та класифікацій механотерапевтичних пристроїв. За переважною спрямованістю впливу тренажери розподіляють на: амплітудно-силові (сприяють збільшенню амплітуди рухів у суглобах верхньої кінцівки, відновлюють порушену функцію захвату і забезпечують тренування сили м'язів кисті та передпліччя); координаторно-рецепторні (тренують координацію рухів і чутливість); комбіновані (володіють одночасним впливом на декілька порушених фрункцій кисті). За принципом дії реабілітаційні тренажери поділяються на: електромеханічні (поєднання електромотора i зусиль людини), механічні (тільки зусилля людини), автоматичні (тільки електромотор без участі людини, пасивні тренування), напівавтоматичні (часткова участь людини), гідравлічні (гідравлічний привід для полегшення рухів), пневматичні (газова пружина для полегшення рухів), інерційні (навантажувальні пружні елементи - пружини, джгути) [3]. За характером роботи дослідники та розробники пропонують таку класифрікацію апаратів механотерапії [2, 8].

1. Діагностичні апарати та апарати з біологічним зворотним зв'язком - допомагають враховувати і точно оцінювати якість руху і відновлення pyxy.

2. Підтримуючі та фріксуючі апарати - допомагають виділяти окремі фрази довільних рухів.

3. Тренувальні апарати і тренажери - допомагають дозувати механічне навантаження під час виконання рухів і вправ.

4. Комбіновані тренажери - дозволяють моделювати не тільки окремі рухи, а й цілісні локомоторні акти, у тому числі й $з$ використанням стабілографрічніх платформ і зворотнього зв'язку $[4,5]$.

Заняття на тренажерах проводять за принципом виконання циклічних стереотипних локомоторних актів верхніх або нижних кінцівок. Це сприяє моделюванню сорормованої у процесі еволюції просторово-часової організації (патерн) нейром'язової активності. Така особливість методу механотерапії $\epsilon$ передумовою фрормування і закріплення більш фрізіологічного патерну відносно існуючого патологічного. Крім того, регулярні заняття на тренажері можуть сприяти зміцненню м'язів при парезах та паралічах, поліпшенню в них кровообігу і обмінних процесів, відновленню порушених рухових функцій, а також поліпшенню психоемоційного стану хворого.

Тракційну терапію широко використовують у фрізичній терапії хворих для зменшення протрузії міжхребцевих дисків, при зсуві диска, викривленні хребта. Функції іiї при травмах 
і захворюваннях хребта - його розвантаження збільшенням відстані між тілами хребців, зменшення патологічного напруження м'язів, зниження тиску всередині міжхребцевих дисків, через що зменшується протрузія, збільшується вертикальний діаметр міжхребцевого отвору, що призводить до декомпресії нервового корінця, зменшення набряку, усунення підвивиху в міжхребцевих суглобах із декомпресійним ефектом. Застосовують «сухе» й «підводне» витягування. «Сухе витягування» - це тракція на звичайному функціональному ліжку. Фіксацію здійснюють за допомогою двох м'яких кілець, що підтримують хворого за пахви (при травмах хребта); застосовують столи спеціальної конструкції з ковзаючим на роликах щитом, що забезпечує добру ефективність процедури через зменшення втрат тяги на тертя [6,7].

У дослідженнях Ю. А. Попадюхи [3, 6] підкреслюється, що до простих тракційних засобів слід віднести портативний тракційний пристрій VERTETRAC для лікування патологічних змін у хребті. Він забезпечує вдосконалений підхід для лікування травм і порушень у поперековому відділі хребта. Це ефективний технічний засіб проведення активної терапії поперекового болю, що викликаний змінами у міжхребцевих дисках та іншими м'язово-скелетними порушеннями, забезпечує швидке відновлення й допомагає запобігти подальшим порушенням диска. Перевагами цього пристрою є короткі відновлювальні сеанси (до 30 хв), свобода рухів, можливість використання в домашніх умовах, активна фрізична терапія.

Можливість ходьби й вільного руху під час і після процедури сприяє переходу людини від положення у згинанні тулоба - до вертикального положення. Це дає змогу м'язам повернутися до стану розслаблення, що потрібно для нормального безболісного відновлення. Пристрій робить можливим повернення рідини в диск, тим самим зменшуючи тиск і, як результат, позбавляє людину болю [4].

За даними Ю. А. Попадюхи апарат ГРЭВИТРИН служить для дозованого аутогравітаційного витягування хребта з метою декомпресії міжхрецевих дисків і їх відновлення, релаксації паравертебральних м'язів, відновлення структур хребта. Процедура такого витягування показана людям,

\section{Література}

1. Кормільцев ВВ. Фізична реабілітація осіб з вертеброгенною патологією в стадії ремісії із застосуванням засобів фітнесу [Physical rehabilitation of persons with vertebrogenic pathology in remission with the use of fitness] [авторефрерат]. Київ; 2014. 24 c. які тривалий час перебувають у позі сидячи, та спортсменам після значних фрізичних навантажень (особливо з дискогенною патологією поперекового відділу хребта). Вплив пристрою на тіло людини здійснюється профрільованою опорною поверхнею, що забезпечує дозоване витягування за умови анатомічно правильної форми й ступеня кривизни хребта. Під дією ваги тіла опорні поверхні ребер, що перебувають у взаємодії з ним, переміщуються в напрямі від попереку $[4,7]$.

У своєму дослідженні П. М. Стецяк зазначав, що технічний засіб David $\epsilon$ інноваційною системою, яка повністю контролює рух в усіх сегментах під час заняття. Система $€$ унікальною, оскільки дозволяє тренуватися навіть пацієнтам 3 серйозними захворюваннями хребта. Вона дозволяє повністю обмежити непотрібні рухи задньої групи м'язів стегна і забезпечити правильну роботу м'язів спини $[3,5]$.

Більшість авторів підкреслюють, що використання зазначених механічних засобів позитивно впливає на стан поверхневих і глибоких, великих і дрібних м'язів хребта, що забезпечують фріксацію хребців і витримують максимальні навантаження в стресових ситуаціях (підйом великого вантажу, різкі гальмування, повороти корпуса, тривале сидіння за кермом автомобіля, за столом).

Також автори відзначають, що тренування на сучасних тренажерах і пристроях ні в якому випадку не замінюють традиційні засоби фрізичної терапії і повинні застосовуватися в комплексі 3 іншими терапевтичними заходами.

Висновки. Аналіз сучасної науково-методичної літератури, узагальнення досвіду провідних фахівців свідчить про те, що застосування різноманітних механотерапевтичних засобів при дискогенній патології поперекового відділу хребта $є$ надзвичайно доцільним і дієвим у комплексному лікуванні хворих. Тема дослідження $€$ актуальною, оскільки розглянуто патологію в осіб саме працездатного віку, яка на сьогодні $€$ дуже поширеною.

Перспективи подальших досліджень. У перспективі планується розробка програми фрізичної терапії для осіб з дискогенною патологією поперекового відділу хребта з використанням технічних засобів.
2. Лазарєва ОБ. Фізична реабілітація хворих із вертеброгенною патологією [Physical rehabilitation of patients with vertebrogenic pathology]. Теорія і методика фіз. виховання і спорту. 2008; 02: 74-78. 
3. Попадюха ЮА. Тренажеры Tergumed с обратной связью в технологиях физической реабилитации, профилактики заболеваний и повреждений позвоночника [Tergumed trainers with feedback in technologies of physical rehabilitation, prevention of diseases and injuries of the spine]. Cовременные здоровьесберегающие технологии. 2016; 4: 251-66 с.

4. Попадюха ЮА. Современные технические средства программы превентивной физической реабилитации повреждений поясничного отдела позвоночника спортсменок художественной гимнастики [Modern technical means of the program of preventive physical rehabilitation of injuries of the lumbar spine in rhythmic gymnastics athletes]. Современные здоровьесберегающие технологии. 2017; 3: 111-114 c.

5. Попадюха ЮА. Сучасні комп'ютеризовані комплекси та системи у технологіях фрізичної реабілітації [Modern computerized complexes and systems in physical rehabilitation technologies]. 2017; 3: 300 c.
6. Попадюха ЮА. Сучасні комплекси, системи та пристрої у реабілітаційних технологіях [Modern complexes, systems and devices in rehabilitation technologies]: Навч. посібник. Київ: Центр учбової літератури; 2018. 656 с.

7. Liberson WT. Active muscular Relahation Techniques. J. of Manipulative and Physiological Therapeatics. 2000;13(1):12-6.

8. Lumbar spine traction: evaluation of effects and recommended application for treatment. Krause M, Refshauge KM, Dessen M, Boland R. Manual Therapy. 2000;(5):72-81.

9. McGill SM. Rehabiliation of the painful back. IDEA Fitness J. 2010,1.

10. Movement control exercise versus general exercise to reduce disability in patients with low back pain and movement control impairment. Saner J, Kool, RA de Bie [et all.] BMC Musculoskelet Disord. 2011;09.

11. Wilts A, Newman R, Machnab N. Spinal stabilityand intersegmental muscle forces. A biomechanical model. Spine. 1999;(14):194-200. 